\title{
COVID-19 Pandemic: Euphemism and Dysphemism in Jordanian Arabic
}

\author{
Sameer Naser Olimat \\ sameer.olimat@bau.edu.jo \\ English Language Department \\ Salt Faculty of Human Sciences \\ Al-Balqa Applied University, Jordan
}

\begin{abstract}
COVID-19 is the major health crisis worldwide nowadays. Linguistic aspects of individuals and communities, including euphemism and dysphemism, were affected by this global challenge because choosing appropriate words to express what speakers intend to say and to reflect what they value or disvalue is a basic part of communication. Euphemism is an acceptable expression used instead of an offensive one to avoid unpleasant connotations, while dysphemism is a derogatory expression with negative suggestions used instead of neutral or polite one to attack something or someone. This paper investigates the use of euphemism and dysphemism in the Jordanian society for dealing with COVID-19. The research was approached from a sociolinguistic perspective and framed mainly within the Theory of Euphemism and Dysphemism by Allan and Burridge (1991; 2006) together with Warren's model of euphemism (1992) and Lakoff and Johnson's Conceptual Metaphor Theory (1980). A sample of 200 Jordanians was asked to respond to a questionnaire including demographic information and closed-ended and open-ended questions. The results show that the Jordanians used different euphemistic techniques in daily COVID-19 conversations, namely, metaphor, shift from Arabic into English, medical terms, and abbreviation. They show that the participants hardly adopted dysphemisms when talking about COVID-19. This paper contributes to the limited investigation of 'pandemic discourse', and to the understanding of euphemistic and dysphemistic tendencies of Jordanians during global crises. Researchers are recommended to explore paralinguistic features of speakers, namely, hand gestures, facial expressions, eye movements, body language, and tone and pitch of voice, while discussing COVID-19 themes.
\end{abstract}

Keywords: Euphemism; Dysphemism; Communication in a Pandemic; Coronavirus; Covid19

\section{INTRODUCTION}

The ongoing spread of the novel coronavirus disease 2019 (henceforth COVID-19) has currently developed to pose a serious global threat to all aspects of daily life. People communicate to maintain good social relationships and strengthen solidarity with others in critical situations by choosing certain kinds of words and linguistic devices. They seek to express themselves in daily conversations through using either indirect or direct language (Olimat, 2018; 2019a, 2019b). Allan and Burridge stated that speakers frequently aim to adopt acceptable or agreeable expressions to safeguard themselves from offensive or frightening things. They may also refer to offensive language as a weapon against others or certain topics or to avoid anger and frustration $(1991 ; 2006)$. Similarly, Rababah (2014) claimed that speakers usually use euphemistic expressions to show their politeness and indirectness towards sensitive issues, and they sometimes resort to dysphemistic expressions to offend taboos or listeners. Farghal (1995) argued that "the language user's option for a euphemism often emanates from contextual factors such as the social relationship between speaker and addressee or the level of formality induced by the setting" (p. 366). Leech (1974) indicated that euphemism is an 
avoidance strategy with a view to ameliorate a particular situation. Euphemism can be defined as a polite term used to discuss a certain topic which speakers may find upsetting or embarrassing to talk about, i.e. sex, bodily parts, diseases, or death. According to Concise Oxford English Dictionary (2004), dysphemism is "a derogatory or unpleasant term used instead of a pleasant or neutral one.". Al-Qadi (2009) indicated that some sensitives issues and social taboos, i.e. infectious diseases, require "mentioning obscene expressions" (p. 18). Therefore, Jordanians may manage communication in challenging circumstances, such as COVID-19 pandemic, through using a variety of neutral, acceptable, direct or less emotive expressions.

Language users endeavour to employ their sufficient knowledge of the choice of words or linguistic devices while communicating with others about COVID-19 to convey comprehensible messages. Jordanians, in particular, have underlying reasons beyond using particular linguistic expressions in lieu of other expressions. Jordan is a relatively conservative society where individuals are influenced by socio-cultural practices or religious beliefs. They have the tendency to use kind, polite, and acceptable expressions, such as pass away instead of die, the late instead of the dead, when simply exchanging information about taboos (Mofarrej and Al-Abed Al-Haq, 2015). Some already existing words describing diseases can, in some cases, be subtly harmful. Such a challenging state of health emergency may encourage Jordanians to use euphemistic expressions to protect themselves since talking about COVID19 directly may cause them to experience huge psychological stress. Jordanians may also attempt to comfort themselves because of the fear of contracting this invisible virus or of family becoming sick. The subject of infectious diseases in the Jordanian community is still regarded as a taboo because of socio-cultural constrains. It has been observed that patients with suspected COVID-19 infections in the Jordanian society have been socially bullied, either online or face-to-face. Therefore, some Jordanians resort to euphemism as an alternative response to avoid socially and culturally distasteful or negative emotions created by COVID19 upon interlocutors. In addition, the fear of stress and anxiety related to isolation and quarantine measures, and the distress of separation from family members may force Jordanians to use indirect language, i.e. euphemism, to keep themselves away from painful and stressful communication. Some Jordanians still deny the truth of COVID-19 virus; hence, euphemism could be a communicative approach for dealing with this issue. Euphemism is a universal linguistic phenomenon for discussing fear-based taboos, such as fatal diseases. In the Jordanian culture, fatal disease-related euphemisms are heavily used to shield the person speaking or hearing death-related words. The fear of death because of COVID-19 virus makes Jordanians find appropriate ways to provide comfort to themselves or to deliver undesirable news of COVID-19 to others indirectly.

Several COVID-19 related terms, e.g. كارثة 'disaster' or عاصفة 'storm' created the impression, for Jordanians, that the pandemic was unavoidable. Therefore, they refer to the use of dysphemistic expressions to camouflage or minimize the effect of COVID-19. Jordanians also adopt dysphemistic expressions to scare their children, relatives, or friends from closely socializing with others. Jordanians express their frustration at politicians who called healthcare workers as 'heroes', rather than seeing the healthcare workers as frightened individuals doing a dangerous job. Consequently, Jordanians use dysphemistic expressions to give warnings about the serious health threat of COVID-19 as well as to call authorities for providing protective measures and policy for health service providers. To conclude, the use of dysphemism, by Jordanians, is sometimes motivated by unpleasant feelings, such as fear, distaste, hatred, and contempt, and it expresses their attitudes towards addressees or the topic of COVID-19.

COVID-19 outbreak has directed my scholarly attentions on examining euphemistic and dysphemistic techniques used by Jordanian Arabic speakers for dealing with this severe 
pandemic. This research attempts to provide a list of frequent polite and offensive expressions in Jordanian Arabic to convey the right message appropriately, to help others understand COVID-19 risks, and to prevent COVID-19 from spreading in the Jordanian society. According to popular databases, such as Elsevier coronavirus centre, Scopus, and Clarivate, almost all recent researches done on COVID-19 have concentrated primarily on public health, medical treatment and vaccines, symptoms and infection microbiology, drug discovery, and clinical information. This research will contribute to studies in linguistics discipline, focusing on euphemism and dysphemism, in particular, to the growing studies in linguistics field about COVID-19. Conducting studies in difficult situations, e.g. COVID-19 global spread, is not an easy task for researchers, resulting in a scarcity of similar studies. Thus, it is hoped the present paper contributes to evaluating euphemistic and dysphemistic strategies used by individuals and societies during critical periods. The research is not only useful for academics in the areas of languages and linguistics but also for broader non-academic community. For example, it permits medical professionals to adopt euphemistic expressions in patient-oriented communication, which may reduce the level of patients' stress and improve their chances of recovery compared to direct doctor-patient communication strategies. It increases the medical practitioners' knowledge that patients feel more positive in response to euphemisms about their true condition, i.e. chances of recovery and positive developments in the patients' health via change of attitudes and beliefs.

COVID-19 pandemic spreads exponentially around the world. Similar to other countries, Jordan has not been immune to the pandemic where 1283 infected cases have been confirmed and 11 people have died from COVID-19 to date (Jordanian Ministry of Health, August 13, 2020). In March 2020, the country declared a state of emergency, and imposed a complete lockdown that lasted for almost two months, including business shutdowns, borders closures, and school and universities moving to online learning mode. Currently, Jordanians are afraid of experiencing a second wave of COVID-19 pandemic. Therefore, investigating the use of euphemism and dysphemism by Jordanian speakers in dealing with this infectious disease has become an inevitable necessity. The present research aims to investigate the use of COVID-19 euphemistic and dysphemistic techniques in the Jordanian society. In other words, it examines how Jordanian speakers shift from Arabic into English, use metaphorical expressions, and use medical abbreviations or terminologies in handling matters about COVID-19. In particular, the research seeks to answer the following questions.

1. Do Jordanians use euphemism more than dysphemism when communicating about COVID-19?

2. What are the most common euphemistic and dysphemistic devices applied by Jordanians when communicating about COVID-19?

3. How does age, gender or education level of Jordanians influence their use of euphemism and dysphemism when communicating about COVID-19?

\section{LITERATURE REVIEW}

Most communication relies on figurative speech, rhetorical tropes, metaphorical expressions, and connotational markers (Gibbs, 1994). Allan and Burridge evaluated the relationship of language taboos and social appropriateness and appropriateness of linguistic expressions (1991; 2006). They classified language expressions into three categories, namely euphemism, i.e. sweet-talk, dysphemism, i.e. impolite talk, and orthophemism, i.e. straight-talk (1991, p. 29). According to Allan and Burridge (1991), euphemism is defined as "an alternative to a dispreferred expression, in order to avoid possible loss of face: either one's own face or, through giving offence, that of the audience, or some third party" (p. 11), whereas dysphemism 
is defined as "an expression with connotations that are offensive either about the denotatum or to the audience, or both, and it is substituted for a neutral or euphemistic expression for just that reason." (p. 26). Olimat (2018) defined euphemism as a metaphoric resource which enables language users to address sensitive or embarrassing issues. He argued that euphemism is an intentional substitution of an offensive, unpleasant or stylistically inappropriate expression with a more agreeable or inoffensive one for conveying a certain meaning implicitly. CrespoFernández (2015) indicated that dysphemism, on the other hand, sheds light on the most pejorative features of a certain taboo with an offensive aim. Thus, speakers have more expressive flexibility in social communication according to the nature of topic or the target audience. Allan and Burridge (1991) claimed that "euphemism and dysphemism are principally determined by the choice of expression within a given context" (p. 4). It can be concluded that euphemism is not the only linguistic means of avoiding taboos, but taboo can be also addressed by another linguistic device, i.e. dysphemism.

Allan and Burridge (1991) described euphemism and dysphemism as "obverse sides of the same coin" (p. 7). Crespo Fernández (2005) indicated that both are common verbal behaviors controlled by conventions of politeness and face concern (p. 78). They are applied to deal with taboo language of painful topics in social discourse and interactions (Fairclough, 1992). It can be concluded that euphemism and dysphemism are examples of linguistic control and refinement since they are specifically directed to employing certain words for socially unspeakable topics. Allan and Burridge (1991) introduced disease as a cross-culturally and diachronically taboo requiring an extensive use of euphemism to soften its potentially undesirable effects, or dysphemism to attack the taboo topic or the addressees. Allan and Burridge (2006) emphasized that people use different language when expressing emotional and social aspects of disease (p. 203). Thus, the choice of language is powerful in circumventing the taboo surrounding embarrassing issues, e.g. COVID-19 disease. Currently, Jordanians are scared and worried about their health and their loved ones that are vulnerable to this unknown virus (Olaimat et al., 2020b) since some countries are experiencing a second wave of COVID19 infections. Therefore, they may resort to euphemism or dysphemism to avoid directly mentioning the anxious thought of COVID-19, i.e. dying.

\section{BACKGROUND TO EUPHEMISM AND DYSPHEMISM IN ARABIC WITH FOCUS ON JORDANIAN ARABIC}

The use of euphemism and dysphemism in the Jordanian context, where is the setting of this research study, has not been fully investigated. Farghal (1993) studied death-related euphemistic and dysphemistic expressions in Jordanian Arabic and found that the metaphorical meaning of death-related euphemisms and dysphemisms can be widely observed in condolences and obituaries. In another study, Farghal (1995) examined the use of colloquial spoken euphemism in Jordanian Arabic. He found that Jordanians mainly use four euphemistic devices, including figurative expressions, circumlocutions, remodelling and antonyms. It seems that both Farghal's studies focused primarily on death- related terms, while other sensitive issues, such as diseases, were overlooked. Al-Azzeh (2009) studied the variation of the degree of using euphemism for dealing with taboos among Jordanian Arabic speakers. The study showed that Jordanians highly employed euphemistic expressions in their social aspects of daily life. Al-Azzeh reported that dialect, age and gender have a strong influence on the choice of euphemism in the Jordanian society. e.g. some euphemisms are exclusive to a specific group of people or a regional area; old people tend to use more euphemisms than young individuals; and females opt for more euphemisms than males. Similarly, the present paper evaluates the variation on the use of COVID-19 euphemisms and dysphemisms by Jordanians according to age, gender, and level of education. 
Rababah (2014) researched the use of X-phemization in medical discourse by health care providers in Jordan. He found that Jordanian medical practitioners used euphemisms, dysphemisms and orthophemisms for different purposes, such as hiding the truth from patients and their families, softening the effect of very blunt or crude messages, providing indirectness of sensitive ideas with health care clients, and concealing the reality of patients' diseases. It is evident that Rababah's study dealt with the reasons beyond using X-phemization by health care providers, whereas the semantic techniques, such as metaphor, shift from Arabic into English, medical abbreviations, and technical terms, were disregarded. Mofarrej and Al-Abed Al-Haq (2015) conducted a sociolinguistic study of death-related euphemistic expressions in Jordanian Arabic. They highlighted the influence of age, gender, and region on the use of euphemism by Bedouin and rural speakers. The findings showed there is an observable variation in the frequency and use of death-related euphemisms among Bedouin and rural participants. Likewise, the current research analyzes the influence of age, gender, and educational level of Jordanians on the use of COVID-19 euphemisms and dysphemisms. Recently, Hazaymeh et al. (2019) explored the socio-cultural and linguistics use of English and French words for euphemism in Jordanian Arabic. The findings indicated that several foreign words were manipulated by Jordanian Arabic speakers to soften the effect of Arabic dysphemistic words on listeners. In this context, the present paper basically examines borrowing or using English words as a euphemistic technique for dealing with COVID-19 disease implicitly.

The phenomena of euphemism and dysphemism in the Arab context have not been also fully investigated. Greis (2000) only discussed euphemism as a linguistic aspect of colloquial and modern Egyptian Arabic, while Khanfar (2012) analysed the typology and formation of euphemism in Iraqi Arabic. Khanfar (2012) found that there is a strong relationship between euphemism and dysphemism. It seems that both Greis (2000) and Khanfar's (2012) studies were based more on impressionistic views as opposed to empirical evidence. ElShiekh (2013) evaluated the use of euphemism in colloquial discourse in Egypt and Jordan. He found that euphemism can be used for several intentions: to avoid a harsh account of an embarrassing situation, to escape from fulfilling duties, to evade answering specific questions, or to elude responsibility. He also found that the Egyptian and Jordanian people heavily used decontextualized quotations, i.e. proverbs and Qur' anic verses, to release themselves from the failure or bearing responsibility. Al-Azzam et al. (2017) explored the feature of euphemism in Saudi Arabic based on the fact that recent socio-cultural pressures and political changes in Saudi Arabia led to creating new euphemistic expressions. Al-Azzam et al. (2017) illustrated that the linguistic behaviour of euphemism by Saudis has changed due to economic growth, educational reform, interfaith dialogue, international interaction and openness, and crosscultural interaction.

Ouzguid (2019) highlighted linguistic and socio-cultural aspects of euphemism in the Moroccan language (Darija) by analysing Moroccan euphemistic examples. The study found that most Moroccans tend to skip sensitive words and use phonemic replacement instead. Nassar and Al-Harahsheh (2020) analyzed socio-pragmatic functions of dysphemistic expressions used in the recent Lebanese Uprising slogans. They found that Lebanese protesters used dysphemistic expressions for several functions, such as expressing change, expressing anger, expressing corruption, expressing persistence, expressing despair, insulting, humiliating, and warning. Individuals and communities appear to communicate differently according to their socio-cultural backgrounds. Yet, most people prefer to use appropriate language while conversing about taboo and embarrassing topics. The majority of the past studies dealt with euphemistic and dysphemistic expressions for common taboos, such as death, sex, and bodily parts and functions; hence, there is still a research gap in the literature on studies in linguistic, in relation to the use of euphemism and dysphemism in infectious diseases, such 
as COVID-19. Therefore, the present paper intends to provide a linguistic analysis on the use and strategies of COVID-19 euphemism and dysphemism in Jordanian Arabic.

\section{LINGUISTICS ANALYSIS DURING OTHER GLOBAL INFECTIOUS DISEASE OUTBREAKS}

Infectious diseases outbreak is not a new occurrence in the world where several countries were affected by overwhelming health threats, such as Ebola, SARS, MERS, and H1N, causing almost global crises. A number of scholars explored how linguistic aspects can be developed in the era of diseases spread, where the use of appropriate language presents a dilemma for interlocutors. Angeli (2012) highlighted the significant role on the use of metaphors in electronic resources about H1N1 and swine flu pandemic. She found that metaphors, such as Swine flu is war and Swine flu is a victimizer, allowed health care recipients to be fully aware of health concerns. Similarly, Balteiro (2017) examined the intention of metaphors in popularized scientific discourse devoted to the Ebola virus. The results showed that war metaphors, such as Ebola is a battle, Ebola is an attack, and Ebola is a killer, were highly applied to enable medical professionals to exchange accurate Ebola information with nonexperts in understandable and friendly terms.

Wallis and Nerlich (2005) examined a set of metaphorical instances on 2003 SARS in UK newspapers. They found that cultural and social factors played a vital role in the formation of SARS metaphors. They demonstrated that conceptual metaphors, e.g. SARS is a killer, were commonly used to evaluate the nature of SARS, its economic and human impact, and individual responses. Shin (2016) examined the role of social cognition and ideology of speakers in using MERS metaphors. Thus, he analyzed how MERS was metaphorically framed in Korean newspapers headlines. He concluded that MERS metaphorical expressions used in Korean newspapers were not too much different from those of other recent severe disease outbreaks. Similarly, Jeon and Yu (2016) explored ideological representations and social interpretations embedded in MERS metaphors in Korean news reports. They analyzed a list of conceptual metaphors, such as MERS is war, MERS is wave, MERS is a living thing, and MERS is a thing. The study uncovered that people's ideology had a huge effect in the choice of MERS metaphors. According to Rawson (1981), Allan and Burridge (1991), and Warren (1992), metaphor is a common semantic approach used by language users to soften or avoid unpleasant topics, such as disease. In general, speakers seek to convey comprehensible messages using indirect or direct language, i.e. euphemism and dysphemism. Currently, Jordanian speakers use metaphorical euphemisms, e.g. COVID-19 is war; a tricky way to discuss the sensitivity and unpleasantness of COVID-19 disease. Joye (2010) examined the news representation of 2003 SARS outbreak in Flemish televisions based on Critical Discourse Analysis (CDA) by Fairclough, (1992; 1995a,b). The research indicated that international news coverage of diseases spread maintains socio-cultural differences amongst communities. Trčková (2015) investigated the conceptualization of the Ebola metaphors in American newspapers using Critical Discourse Analysis (CDA) (Fairclough, 1992; van Dijk, 1993; Weiss and Wodak, 2003; Wodak and Meyer, 2009) and the Cognitive Theory of Metaphor (Lakoff and Johnson, 1980; 1999). The analysis showed that American newspapers had a predominant reliance on the conceptual metaphor Ebola as war although other two metaphors of Ebola as an animate/human being and Ebola as a natural catastrophe were alternatively adopted.

The originality of the present study comes from the fact that this is the first study on linguistic analysis on the use of euphemism and dysphemism in the Jordanian society during challenging circumstances, i.e. COVID-19 pandemic. Past studies examined the use of euphemism and dysphemism in Jordan in particular and in Arab countries in general, but a research gap on the use of euphemism and dysphemism for dealing with infectious diseases still exists. Therefore, this research is a sociolinguistic investigation on the use of COVID-19 
euphemism and dysphemism in Arabic context, particularly Jordanian Arabic. It is hoped that this research work will fill in the literature gap on the linguistic analysis on euphemism and dysphemism in Jordan due to the limited investigation of 'pandemic discourse' in general, and to the understanding of euphemistic and dysphemistic tendencies of Jordanians during international crises, in particular.

\section{THEORETICAL FRAMEWRK}

Language users refer to euphemism and dysphemism to conceptualize unspeakable topics to reduce the reality of prohibited issues (Gomez, 2009, p. 738). From a cognitive perspective, euphemistic or dysphemistic expressions are used to name things without changing their mental picture, i.e. the reality and nature of things are not distorted in the speaker's mind (Mihas, 2005). Lakoff and Johnson (1980) proposed the Conceptual Metaphor Theory which suggests that metaphor is a cognitive process in which an experimental domain is partially mapped onto a different domain which is perceived based on the first one. The domain that is mapped is named the source, while the domain that is mapped onto is named the target. Metaphors function for either highlighting or concealing. That is, metaphor allows interlocutors to recognize a specific feature of a certain concept in terms of another concept, but this could cover other features of the concept. Based on this cognitive view, the source domain, i.e. euphemism or dysphemism is mapped systematically to the target domain, i.e. taboo. Thus, speakers resort to euphemism to highlight positive, convenient, or agreeable aspects but also to hide negative, distasteful, or embarrassing aspects of the target domain. On the other hand, speakers resort to dysphemism to attack or reduce painful or offensive features of the target domain.

According to Allan and Burridge (1991; 2006), and Warren (1992), there are several euphemistic and dysphemistic approaches in language, namely (i) word formation devices including compounding, derivation, blends, acronyms, and onomatopoeia, (ii) phonemic modification including back slang, rhyming slang, phonemic replacement, and abbreviation, (iii) loan words deriving from French, Latin and other languages, and (iv) semantic devices including particularization, implication, metaphor, metonym, reversal or irony, understatements or litotes, and overstatements or hyperbole. These linguistic categories were tested against the participants' euphemistic and dysphemistic response to the two open-ended questions in the survey.

\section{METHODOLOGY}

\section{DATA COLLECTION INSTRUMENT}

A two-section questionnaire designed to examine the use of euphemistic and dysphemistic expressions by Jordanian speakers for communicating about COVID-19 was carefully developed (appendix A). Before designing the questionnaire, the researcher studied the linguistic definition, purposes, and functions of euphemism and dysphemism. He also revised past related studies on the use of euphemism and dysphemism in Arabic language generally and the Jordanian Arabic particularly (Farghal (1993; 1995), Greis (2000), Al-Azzeh (2009), Khanfar (2012), ElShiekh (2013), Rababah (2014), Mofarrej and Al-Abed Al-Haq (2015), and Al-Azzam et al. (2017), Olimat (2018), Hazaymeh et al. (2019), Ouzguid (2019), and Nassar and Al-Harahsheh (2020)). In addition, the researcher considered the Jordanians' knowledge about viral sources, incubation period, mortality rate, transmission, symptoms and complications, and sources of information about COVID-19. He also evaluated behavioral 
practices and attitudes of Jordanians toward social distancing and preventing COVID-19. (Olaimat et al, 2020a,b).

In the first section of the questionnaire, the participants were asked to provide demographic information relating to their gender, age, and educational level. The second section of the questionnaire included two types of questions: closed-ended, i.e. yes-no, and open-ended. The participants were asked to provide as many appropriate responses as they can for the open-ended questions. The questionnaire was given to two professors at two different Jordanian universities to evaluate the questionnaire. The first is a full professor of curriculum and instruction at Faculty of Educational Sciences at the University of Jordan, and the second is an associate professor of sociolinguistics and pragmatics at Faculty of Arts at Yarmouk University. They published several articles in peer-reviewed and specialized journals and participated in various national and international peer-reviewed conferences. Some modifications in the final version of the questionnaire were made based on their feedback and suggestions. For example, both advised to study the influence of the Jordanians' educational level on the choice of euphemism and dysphemism since this variable measures the knowledge and satisfaction of the respondent towards the investigated topic. The second recommended to add a yes-no question about shift from Arabic into English since it is a common linguistic phenomenon in the Jordanian community to deal with severe diseases, such as Alzheimer, heart failure, and cancer. Moreover, both suggested to delete an open-ended question about the role of social media in the use of euphemism and dysphemism since it does not help much in discussing the rationale of the research, and it is not connected to the research goals directly. To explain in greater detail, the first two closed-ended questions in the survey were meant to find answers for research question number 1 (Do Jordanians use euphemism more than dysphemism when communicating about COVID-19?). The third and the fourth closed-ended questions in the questionnaire attempted to provide answers for research question number 2 (What are the most common euphemistic and dysphemistic devices applied by Jordanians when communicating about COVID-19?). Specifically, the third closed-ended question attempted to find an answer about a frequent linguistic device of euphemism and dysphemism, i.e. shift from Arabic into English, in the Jordanian society to deal with painful diseases, such as cancer. According to Warren's model (1992), shift from one language into another is a popular semantic approach for dealing with unpleasant topics. The fourth closed-ended question was asked to find out about the use of the scientific abbreviation 'COVID-19' by Jordanians because it is the most commonly used term globally and locally (media, TVs, newspapers, governments' daily briefing, the WHO). Warren's model (1992) of euphemism indicated that the use of technical terms or scientific abbreviations is heavily applied by speakers to deal with taboo topics. However, other abbreviated conditions related to COVID-19, such as Hypertension (HT), Severe Acute Respiratory Syndrome (SARS), and Diabetes Mellitus (DM), can be further explored in the near future. Similarly, the two open-ended questions in the questionnaire attempted to find answers for research question number 2 based on euphemistic and dysphemistic classifications suggested by Allan and Burridge $(1991 ; 2006)$ and Warren (1992). More elaboration on research question number 3 (How does age, gender or education level of Jordanians influence their use of euphemism and dysphemism when communicating about COVID-19?) is in Data about Participants section. Data was collected online because it was not feasible to do a community-based sampling survey during this critical period in Jordan where the lockdown of all cities was completely decided by authorities. A link to the questionnaire hosted on Google Drive (https://docs.google.com/forms/d/e/1FAIpQLSeYG3mFs33-gUAtvYTE0k_0-

XjF4vTC31wwMrYVxpkPMNtLNg/viewform?usp=sf_link) was distributed through the most common social media channels amongst Jordanians, namely, Facebook and WhatsApp. The questionnaire was written and distributed in Arabic to guarantee a complete understanding of 
the questions. The participants were given a chance to fill in the questionnaire and return their responses. Then, the collected participants' responses to the open-ended questions were literally translated into English in Discussion and Findings section. Based on research ethics and confidentiality, general information about the research and a consent question were included in the introductory part of the survey. The participants were given a brief introduction of the research purposes, and then were asked whether they would like to take part in this questionnaire or not (Appendix A). They were informed that their participation in this research is entirely voluntary. They were also informed that they will not be identified in the publication, and the collected data will remain strictly confidential, i.e. only anonymised data will be published in academic journals. Furthermore, they were informed that they have the right to ask for further information, withdraw from participating if they felt stressed or unwilling to do so, and avoid answering any questions if they do not want to without giving reasons.

\section{DATA ABOUT PARTICIPANTS}

A sample of 200 Jordanian Arabic speakers from the Jordanian population was chosen for the present study representing different levels of education, ages, and gender. The researcher made the questionnaire accessible to all Jordanians on Facebook and WhatsApp. Figure 1 illustrates the proportion of gender, age, and educational level of the selected participants who filled in the questionnaire. In order to answer research question number 3, the influence of the three variables on the use of euphemistic and dysphemistic techniques by Jordanians while communicating about COVID-19 was examined. The sample of participants comprises 96 males and 104 females, with different age range, i.e. 46 participants are between 16 years and less than 20 years, 58 participants are between 20 years and less than 40 years, 66 participants are between 40 years and less than 60, and 30 participants are 60 years or above. The data also shows that there are three levels of education, with 40 participants having secondary education or less, 102 participants holding a Bachelor degree, and 58 participants holding graduate degree.
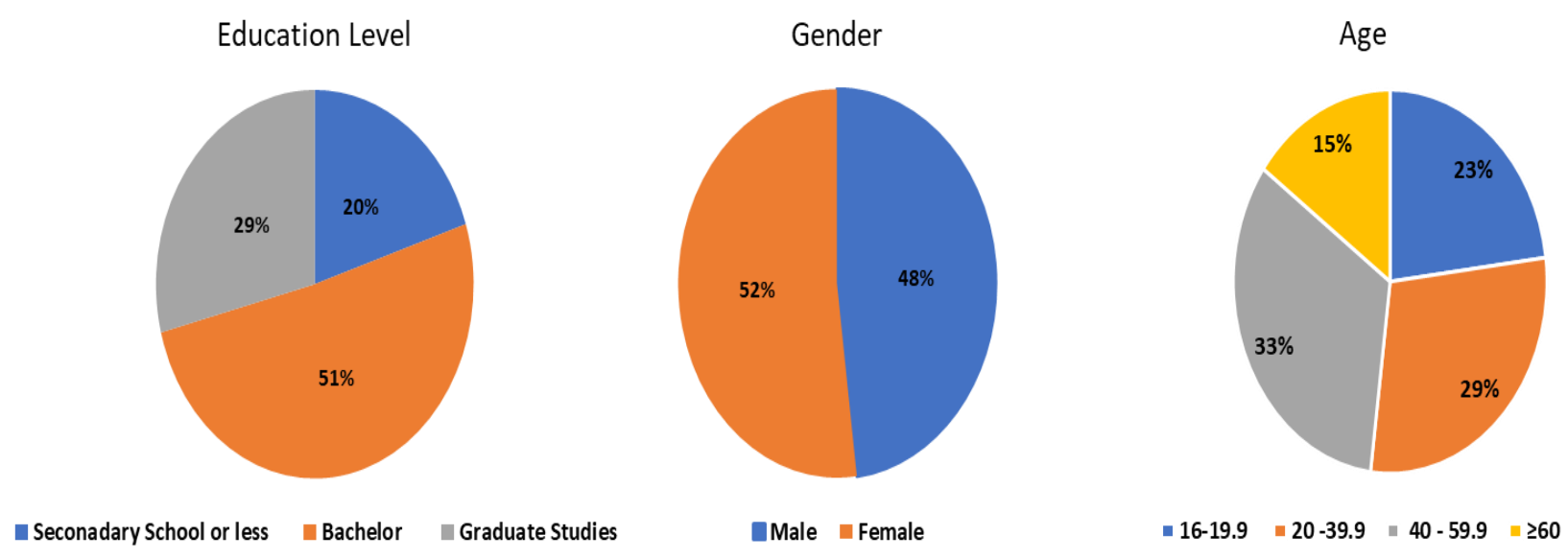

FIGURE 1. The distribution of the age, gender and educational level of the participants.

\section{DATA ANALYSIS PROCEDURES}

The Statistical Package for Social Sciences (SPSS) is a widely used program to do statistical analysis in the areas of social science and health (version 25, IBM Corporation, Armonk, NY). The collected participants' responses to the four closed-ended questions were imported into 
Excel for coding and then SPSS for analysis. Numbers and percentages were used in the research discussion to explore to what extent euphemistic and dysphemistic expressions used by Jordanians while communicating about COVID-19. Frequency distributions were also established to assess potential statistical relationships between sociodemographic, i.e. gender, age, and educational level, and the choice of COVID-19 euphemism or dysphemism.

The participants' responses to the open-ended questions, which focus on common COVID-19 euphemistic and dysphemistic utterances, were also imported into Excel for coding, and then analysed from a sociolinguistic perspective. Bar charts were used to give a quick summary and a general view of the findings to the reader. Since the questionnaire was written and distributed in Arabic, the researcher produced a literal English translation of the participants' responses in the Findings and Discussion section. Because the setting of the research was in Jordan, the collected responses were evaluated and compared with the findings of related studies previously conducted on the use of euphemism and dysphemism in the Jordanian context in particular, such as Farghal (1993; 1995), Al-Azzeh (2009), Rababah (2014), Mofarrej and Al-Abed Al-Haq (2015), Hazaymeh et al. (2019), and the Arab context in general, such as Greis (2000), Khanfar (2012), ElShiekh (2013), Al-Azzam et al. (2017), Ouzguid (2019), and Nassar and Al-Harahsheh (2020)). The collected participants' responses to the open-ended questions were classified into different euphemistic and dysphemistic devices according to Allan and Burridge (1991; 2006) and Warren (1992).

\section{FINDINGS AND DISCUSSION}

\section{YES-NO QUESTIONS}

The first yes-no question deals with the Jordanians' preference of euphemism in linguistic communication about COVID-19 (Appendix A). Table 1 shows that the majority of the participants preferred to use euphemistic expressions when dealing with COVID-19 in daily conversations. It has been found that 170 participants responded with a 'yes', which constitutes $85 \%$ of the total number of the study population. Allan and Burridge (1991) defined euphemism "as an alternative to a dispreferred expression, in order to avoid possible loss of face: either one's own face or, through giving offence, that of the audience, or some third party." (p. 11). Wardhaugh (2006) claimed that the unpleasantness of taboo topics, e.g. diseases, requires to be more neutralized or polite by euphemistic terms (p. 240). It seems that Jordanians tended to use "alternative" terms (Allan and Burridge, 1991, p. 11) for dealing with COVID-19 in verbal communication. The Jordanians' production of COVID-19 euphemisms was also investigated according to gender, age, and educational level. Table 1 shows that $86.5 \%$ of the females and $83.3 \%$ of the males expressed their desire for using euphemistic terms when talking about COVID-19. This means that there is no big difference in the use of COVID-19 euphemisms amongst the Jordanian females and males. This finding contradicts past studies which reported that 'gender' is the variable that develops the different patterns of the language use, where women are more likely to use decent expressions to show their politeness than men do (Lakoff, 1975; Cameron, 1995; Al-Shamali 1997; Holmes, 1998). By contrast, this finding lends support to Crawford and Chaffin (1987), Rabab'ah and Al-Qarni (2012), and Al-Khasawneh (2018) who claimed that no difference between males and females in the linguistic production of euphemism exists. Since context plays a significant role in identifying potential meanings of words, conducting a descriptive study on associated circumstances which may contextualize COVID-19 communication and may influence the language use of participants, such as the social rank of addressees, i.e. superior, equal, inferior; where they are talking, i.e. school, university, home, work, hospital, and supermarket; and the social relationship between 
speakers and addressees, i.e. family member, friend, and acquaintance (Mofarrej and Al-Abed Al-Haq; 2015) is suggested.

The role of age is considered in the areas of sociolinguistics and language change (Eckert, 1997). Speakers with different ages normally behave in different ways. Table 1 shows that all participants whose age ranges from 16 years to less than 20 years prefer to use euphemistic expressions when addressing COVID-19 topics. There is a considerable similarity in the preference of euphemism between those whose age ranges from 20 years to less than 40 years and those whose age ranges from 40 years to less than 60 years. The table further illustrates that nearly two-third of the selected participants whose age is 60 years or above produced euphemisms to avoid unpleasant effects of COVID-19. It can be concluded that the production of euphemisms varies with the speakers' age. This result totally agrees with Ren and Yu (2013) who mentioned that age is a decisive factor in the employment of euphemism. Level of education is one of the most universally accepted factors in the language use since it brings major changes to the speakers' choice of words. Intellectual people often look for polite and agreeable expressions to improve their ways of linguistic communication. Table 1 shows that $80 \%$ of the participants with a secondary education or less preferred to use euphemisms when talking about COVID-19. Roughly $85 \%$ of the participants who hold a Bachelor degree tended to adopt euphemisms for dealing with COVID-19. The data indicates that nearly $90 \%$ of the participants, who hold a Master or $\mathrm{PhD}$ degree, strongly preferred to use euphemisms for COVID-19. It can be understood that highly educated Jordanians have a positive attitude towards using euphemistic expressions more than others. This gives evidence that the choice of euphemisms is affected by the speakers' level of education.

TABLE 1. The participants' responses to the preference of euphemism.

\begin{tabular}{|c|c|c|c|c|}
\hline \multirow{2}{*}{$\begin{array}{l}\text { Demographic } \\
\text { variable }\end{array}$} & \multirow{2}{*}{ Category } & \multirow{2}{*}{$\mathbf{N}$} & \multicolumn{2}{|c|}{ Frequency and Percentages $(\%)$} \\
\hline & & & Yes & No \\
\hline \multirow{4}{*}{ Age } & 16-19.9 years & 46 & $46(100 \%)$ & $0(0 \%)$ \\
\hline & 20-39.9 years & 58 & $48(82.8 \%)$ & $10(17.2 \%)$ \\
\hline & 40- 59.9 years & 66 & $56(84.8 \%)$ & $10(15.2 \%)$ \\
\hline & $\geq 60$ years & 30 & $20(66.7 \%)$ & $10(33.3)$ \\
\hline Total & & 200 & $170(85 \%)$ & $30(15 \%)$ \\
\hline \multirow{2}{*}{ Gender } & Female & 104 & $90(86.5 \%)$ & $14(13.5 \%)$ \\
\hline & Male & 96 & $80(83.3 \%)$ & $16(16.7 \%)$ \\
\hline \multirow{2}{*}{ Total } & & 200 & $170(85 \%)$ & $30(15 \%)$ \\
\hline & Secondary or less & 40 & $32(80 \%)$ & $8(20 \%)$ \\
\hline \multirow[t]{2}{*}{ Educational Level } & Bachelor degree & 102 & $86(84.3 \%)$ & $16(15.7 \%)$ \\
\hline & Graduate studies & 58 & $52(89.7 \%)$ & $6(10.3 \%)$ \\
\hline Total & & 200 & $170(85 \%)$ & $30(15 \%)$ \\
\hline
\end{tabular}

The second yes-no question examines the Jordanians tendency to the use of dysphemism for dealing with COVID-19 in everyday situations (Appendix A). McArthur (1992) defined dysphemism as "the use of a negative or disparaging expression to describe something or someone" (p. 328). According to Allan and Burridge (1991, 2006), dysphemism is an offensive word with derogatory connotations directed to contempt a neutral or euphemistic topic for a specific reason. Table 2 shows that most of the participants did not use dysphemistic expressions when talking about COVID-19. The data reveals that only 38 participants, constituting $19 \%$ of the sample population, resorted to strong language for reducing the effect 
of COVID-19. This finding completely is in line with what is concluded from question 1 that the majority of Jordanians preferred to produce euphemisms while conversing about COVID19. The table shows that nearly a quarter of the male participants referred to dysphemistic words when talking about COVID-19, while around only $15 \%$ of the female participants did so. This asserts that women try to express their sensitivity and kindness more than men when describing COVID-19 taboo. This finding lends support to Al-Khasawneh (2018) who indicated that females are more disposed than males to avoid taboos. It also entirely agrees with the universal tendency of women's adoption of the more socially prestigious language. Lakoff (1975) and Greene (2000) stated that the linguistic communication and speeches produced by females often suggest polite, sympathetic and respectful messages. In conclusion, it seems that gender is a vital factor in the language use of people.

The use of language is often affected by the speaker's age. Jordanians' reliance on dysphemism for describing COVID-19 according to their ages was examined. Table 2 demonstrates that only $13 \%$ of the participants, whose age ranges from 16 years to less than 20 years, preferred using dysphemistic terms while talking about COVID-19. There is no big difference in the use of dysphemism for describing COVID-19 for Jordanians whose age ranges from 20 years to less than 60 years. One-third of the participants whose age is 60 years or above preferred offensive expressions when communicating about COVID-19. This finding absolutely disagrees with the universal tendency of elderly people to prompt more euphemized and socially appropriate utterances. For example, Mofarrej and Al-Abed Al-Haq (2015) found that the old Jordanians used more euphemized expressions than those who are 30 years old or under. The level of education also plays a major role in social communication. It is assumed that highly educated people prefer to use acceptable language in daily conversations to show their civilization and kindness. The data reveals that only $15 \%$ of the participants with a secondary certificate or less selected dysphemistic expressions when speaking about COVID19, whereas around $20 \%$ of the participants with a Bachelor, Master or PhD degree did so. This means that the use of COVID-19 related dysphemism in Jordanian Arabic is not highly affected by language user's level of education.

TABLE 2. The participants' responses to the preference of dysphemism.

\begin{tabular}{|c|c|c|c|c|}
\hline \multirow{2}{*}{$\begin{array}{l}\text { Demographic } \\
\text { variable }\end{array}$} & \multirow{2}{*}{ Category } & \multirow{2}{*}{$\mathbf{N}$} & \multicolumn{2}{|c|}{ Frequency and Percentages $(\%)$} \\
\hline & & & Yes & No \\
\hline \multirow{4}{*}{ Age } & 16-19.9 years & 46 & $6(13 \%)$ & $40(87 \%)$ \\
\hline & $20-39.9$ years & 58 & $10(17.2 \%)$ & $48(82.8 \%)$ \\
\hline & 40- 59.9 years & 66 & $12(15.2 \%)$ & $54(84.8 \%)$ \\
\hline & $\geq 60$ years & 30 & $10(66.7 \%)$ & $20(33.3)$ \\
\hline Total & & 200 & $38(19 \%)$ & $162(81 \%)$ \\
\hline \multirow{2}{*}{ Gender } & Female & 104 & $16(15.4 \%)$ & $88(84.6 \%)$ \\
\hline & Male & 96 & $22(22.9 \%)$ & $74(77.1 \%)$ \\
\hline \multirow[t]{2}{*}{ Total } & & 200 & $38(19 \%)$ & $162(81 \%)$ \\
\hline & Secondary or less & 40 & $6(15 \%)$ & $34(85 \%)$ \\
\hline \multicolumn{5}{|l|}{ Educational } \\
\hline \multirow[t]{2}{*}{ Level } & Bachelor degree & 102 & $20(19.6 \%)$ & $82(81.4 \%)$ \\
\hline & Graduate studies & 58 & $12(20.7 \%)$ & $46(79.3 \%)$ \\
\hline Total & & 200 & $38(19 \%)$ & $162(81 \%)$ \\
\hline
\end{tabular}

The third yes-no question evaluates the Jordanians' shift from Arabic into English while discussing COVID-19 in verbal communication (Appendix A). The data analysis illustrates 
that one-third of the selected sample opted to use English words when talking about this disease. They borrowed English words, such as coronavirus, corona, the virus, and COVID19. This means that two-third of the sample population had the tendency to use their mother tongue, Arabic, for describing COVID-19. Rababah (2014) found that nearly 43\% of the health care providers switched from Arabic into English, for euphemistic purposes, instead of being directly with health care clients. English has historically developed its vocabulary by borrowing many words from other languages. For instance, a great number of medical terms in English have originally come from Latin and Ancient Greek. Similarly, Arabic language has enriched its terminology when using foreign words as euphemistic substitutes. For instance, the English word Madam is used in Arabic in the same way as a polite form of address amongst educated and high-class speakers. Table 3 shows that both the female and male participants equally expressed their tendency to use English words when communicating about COVID-19, with nearly one-third for each. They may refer to English language to deal with this infectious disease indirectly in spite of the recentness and novelness of the virus. By contrast, the direct use of the English terms for talking about diseases is called orthophemisms since it deals with the reality of diseases objectively. However, Williams (1975) considered borrowing foreign words a major resource of generating euphemisms in a language. Similarly, Warren (1992) suggested that the phenomenon of euphemism in English relied basically on using loan words from Latin, French and other languages. For instance, mot is used in lieu of the female genital organ (Allan and Burridge, 1991, p. 95), and affair(e) and lingerie are used as euphemistic substitutes for extramarital engagement and underwear respectively (Stern, 1931). It can be concluded that positive communication can be created by borrowing words and phrases, with little or no modification, from other languages. Table 3 shows that two-third of both females and males showed their preference for Arabic language when talking about COVID-19. They may disregard English because of its sophisticated culture-specific implications for Jordanian Arabic speakers. This suggests that Arabic probably imposes socio-cultural restrictions on the use of foreign words compared with English that retains more flexibility and freedom for borrowing alien words. To sum up, there is no difference between Jordanian men and women with regards to switching from Arabic into English when addressing COVID-19.

Table 3 illustrates that more than half of the participants, whose age ranges from 16 years to less than 20 years, had the tendency to describe COVID-19 using English words. The table also shows that $37.9 \%$ of the participants, whose age ranges from 20 years to less than 40 years, preferred English for dealing with COVID-19. This strong preference of English is due to several reasons. Firstly, English remains a major medium of communication and knowledge dissemination in the world since it is widely spoken and universally accepted in different areas of life. Therefore, youths in Jordan use English in various aspects of daily life, such as social media channels, listening to songs, and watching TV series or movies. Secondly, English has recently been the language of teaching and technology at schools and universities in Jordan; hence, it is easier for Jordanians to express themselves in English. Thirdly, English is a social indicator for people with higher education and social high-class status. Thus, younger generation of Jordanians may use English to make a really big impression and to attract others' attention while discussing COVID-19 in English. Jordanians may develop new lexical items for euphemistic functions, i.e. mitigating potential offence, when they use English Covid-19 terms.

It has been found that about $24 \%$ of the participants whose age ranges from 40 years to less than 60 years and $13 \%$ of the participants, whose age is 60 years or above used English when talking about COVID-19. This indicates that the majority of Jordanians used Arabic instead of English to communicate about COVID-19. Regarding the influence of educational level of Jordanians on the use of English in daily COVID-19 conversations, data in table 3 discloses that only $20 \%$ of the participants with a secondary degree or less used English words 
for describing COVID-19. More than one-third of the participants with a Bachelors degree and graduate studies employed English utterances while speaking about COVID-19 because English is the main language of professional and academic communication in higher education in Jordan where they have more English resources and references for COVID-19. It can be inferred that the Jordanians' use of English COVID-19 terms is affected by the level of education.

TABLE 3. The participants' responses to the preference of shift into English.

\begin{tabular}{|c|c|c|c|c|}
\hline \multirow{2}{*}{$\begin{array}{c}\text { Demographic } \\
\text { variable }\end{array}$} & \multirow{2}{*}{ Category } & \multirow{2}{*}{$\mathbf{N}$} & \multicolumn{2}{|c|}{ Frequency and Percentages (\%) } \\
\hline & & & Yes & No \\
\hline \multirow{4}{*}{ Age } & 16-19.9 years & 46 & $26(56.5 \%)$ & $20(43.5 \%)$ \\
\hline & 20-39.9 years & 58 & $22(37.9 \%)$ & $36(62.1 \%)$ \\
\hline & 40- 59.9 years & 66 & $16(24.2 \%)$ & $50(75.8 \%)$ \\
\hline & $\geq 60$ years & 30 & $4(13.3 \%)$ & $26(86.7 \%)$ \\
\hline Total & & 200 & $68(34 \%)$ & $132(66 \%)$ \\
\hline \multirow{2}{*}{ Gender } & Female & 104 & $36(34.6 \%)$ & $68(65.4)$ \\
\hline & Male & 96 & $32(33.3 \%)$ & $64(66.7 \%)$ \\
\hline Total & & 200 & $68(34 \%)$ & $132(66 \%)$ \\
\hline & Secondary or less & 40 & $8(20 \%)$ & $32(80 \%)$ \\
\hline \multicolumn{5}{|l|}{ Educational } \\
\hline \multirow[t]{2}{*}{ Level } & Bachelor degree & 102 & $38(37.3 \%)$ & $64(62.7)$ \\
\hline & Graduate studies & 58 & $22(37.9 \%)$ & $36(62.1)$ \\
\hline Total & & 200 & $68(34 \%)$ & $132(66 \%)$ \\
\hline
\end{tabular}

The four yes-no question examines Jordanians' use of medical terms and abbreviations about COVID-19 in their social interactions (Appendix A). Table 4 shows that only 34 of the participants used the technical term 'COVID-19' in daily conversations, which constitutes only $17 \%$ of the sample. Technical terms are an integral part of a language used by specialists in the context of professional activities, and they can be gradually popularized by speakers. Huang (2005) and Allan (2012) indicated that language users euphemistically adopt technical jargons, such as mentally challenged and mental disorders, in place of common offensive words, such as crazy or insane. More than $80 \%$ of the sample did not use the medical abbreviated term 'COVID-19' in social communication. Tayler and Ogden (2005) found that using medical terms may result in negative effects on patients' emotions or their family because it reflects a higher level of risk than desired by doctors. Holder (2008) claimed that medical jargons, such as agonal or calcium oxalate stone, are used by doctors in place of generally understandable reference to serious diseases. According to Rababah (2014), the health care providers sometimes shift to technical terms, scientific names, or medical abbreviations, such as disorder, Diazepam, and AIDS, to hide the truth from health care clients. Almasaeid (2016) argued that doctors often switch to technical terminologies, such as neoplasia to avoid the direct use of cancer in front of patients or their relatives. It seems that the Jordanians' little use of scientific abbreviation 'COVID-19' can be attributed to their insufficient knowledge of the novel disease at the beginning of coronavirus outbreak as well as the serious effect of this term on interlocutors.

From a linguistic perspective, the abbreviation 'COVID-19' stands for Corona Virus Disease 2019. Allan and Burridge (1991) classified abbreviation as a morphological method for producing euphemisms. Warren (1992) considered abbreviation a phonemic approach of euphemism in which the structural form of a tabooed word is altered. According to Neaman 
and Silver (1983a; 1983b), abbreviation is a euphemistic technique by which a group of tabooed words is reduced into one of its parts. Rabab'ah and Al-Qarni (2012) presented abbreviation as an indirect euphemistic substitution for a disagreeable expression. Almasaeid (2016) observed that people may refer to abbreviations for euphemistic functions, such as the big $C$ or c.a. instead of cancer. It can be concluded that the abbreviation 'COVID-19' has become a universal euphemistic alternative for 'Corona Virus Disease 2019'. The data analysis shows that more than $80 \%$ of the participants with different gender, ages and levels of education did not use the abbreviated form 'COVID-19' at all. In brief, speakers can use medical terms, scientific names, and abbreviations for euphemistic goals, but their linguistic use in daily conversations requires a deeper knowledge and understanding of the original term by addressees.

TABLE 4. The participants" responses to the preference of medical abbreviated terms.

\begin{tabular}{|c|c|c|c|c|}
\hline \multirow{2}{*}{$\begin{array}{c}\text { Demographic } \\
\text { variable }\end{array}$} & \multirow{2}{*}{ Category } & \multirow{2}{*}{$\mathbf{N}$} & \multicolumn{2}{|c|}{ Frequency and Percentages (\%) } \\
\hline & & & Yes & No \\
\hline \multirow{4}{*}{ Age } & 16-19.9 years & 46 & $10(21.7 \%)$ & $36(78.3 \%)$ \\
\hline & 20-39.9 years & 58 & $8(13.8 \%)$ & $50(86.2 \%)$ \\
\hline & 40- 59.9 years & 66 & $10(15.2 \%)$ & $56(84.8 \%)$ \\
\hline & $\geq 60$ years & 30 & $6(20.0 \%)$ & $24(80.0 \%)$ \\
\hline Total & & 200 & $34(17 \%)$ & $166(83 \%)$ \\
\hline \multirow{3}{*}{ Gender } & Female & 104 & $16(15.4 \%)$ & $88(84.6 \%)$ \\
\hline & Male & 96 & $18(18.8 \%)$ & $78(81.3 \%)$ \\
\hline & & 200 & $34(17 \%)$ & $166(83 \%)$ \\
\hline Total & Secondary or less & 40 & $8(20.0 \%)$ & $32(80.0 \%)$ \\
\hline \multicolumn{5}{|l|}{ Educational } \\
\hline \multirow[t]{2}{*}{ Level } & Bachelor degree & 102 & $16(15.7 \%)$ & $86(84.3 \%)$ \\
\hline & Graduate studies & 58 & $10(17.2 \%)$ & $48(82.8 \%)$ \\
\hline Total & & 200 & $34(17 \%)$ & $166(83 \%)$ \\
\hline
\end{tabular}

\section{OPEN-ENDED QUESTIONS}

The two open-ended questions in the survey were written in Arabic (c.f. Methodology section). Therefore, the participants' Arabic response used for describing 'COVID-19' were collected in Excel for coding. A literal English translation of these responses was provided in the following discussion to offer a better understanding for the reader. The participants' responses were evaluated based on past related studies. The first open-ended question investigates euphemistic expressions used by Jordanians for communicating about COVID-19 in daily conversations (Appendix A). Figure 2 shows that 'corona' was the most common expression used by the participants to facilitate the act of communication about this disease, at 118 times. In English dictionaries, the word 'corona' means 'wreath' or 'crown' which suggests positive connotations. It seems that those speakers applied two linguistic techniques at the same time, i.e. metaphorization and deletion. Warren (1992) claimed that metaphor is a popular semantic approach for dealing with offensive topics. According to Lakoff and Johnson's Conceptual Theory (1980), metaphoric expressions function for either highlighting or concealing. Therefore, the participants highlighted the positive or convenient aspect, i.e. corona, whereas the distasteful or taboo aspect, i.e. virus, was concealed or removed. Rabab'ah, and Al-Qarni (2012) mentioned that deletion is the most frequently used strategy by Saudis for dealing with the concept of death in informal situations. Al-Adwan (2015) introduced omission as a 
euphemistic approach for alleviating threatening messages beyond uttering negative lexical items. The participants may resort to the technique of deletion because it may make them feel less anxious and depressed than those who use the word 'coronavirus' directly. The direct use of COVID-19 terminology may make Jordanians afraid of its bad consequences, i.e. death. Therefore, they used deletion technique to avoid mentioning it openly.

The term 'coronavirus' occupied the second rank at 56 times. The participants may assume that switching into English could conceal or, at least, minimize the potential offence of the tabooed effect of COVID-19. Al-Khatib and Sabbah (2008) found that some Jordanian university students sometimes shifted from Arabic to English in mobile text messages to discuss taboos freely. It can be concluded that adopting a foreign word with less negative associations is a useful way to avoid the unpleasant effect of the direct use of an offensive Arabic word, such as الوباء 'the pandemic', أزمة 'crisis', and 'plague'. Nonetheless, using the shortened version corona instead of coronavirus could merely be for convenience purposes, i.e.an easy way for informal speaking.

Figure 2 shows that the two words المرض 'the disease' and 'the virus' came in the third rank at 32 times for each. The word المرض 'the disease' has been most commonly used in Arab societies as a euphemistic alternative for 'cancer'. ElShiekh (2013) observed that some Egyptian and Jordanian speakers frequently adopt colloquial euphemisms, such as المرض الوحش 'the bad disease' to avoid mentioning openly the cancer disease in everyday conversations. Similarly, Almasaeid (2016) indicated that Arabic speakers refer to المرض الخييث 'the malignant disease' as a euphemistic replacement of the cancer disease. Al-Azzam et al. (2017) pointed out that Saudis seek to euphemistically describe the cancer disease, rather than name it directly, through using الثين 'bad' or الخبيث 'malignant'. In Jordan, people get used to employing indirect utterances for dealing with the cancer disease, such as المرض 'the disease'. It is evident that some of the selected participants adopted a similar technique with COVID-19 by using words with less negative connotations, i.e. المرض 'the disease' and 'الفيروس 'the virus', which have less negative effect upon the addressees. The word غيمة 'cloud' was used by 22 Jordanian participants because in Arabic culture this word suggests making something invisible or dark for a short period. Jordanians may choose this euphemistic term hoping that COVID-19 outbreak will not last.

However, 19 كو فيد 'COVID-19', الفيروس المستجد 'the novel virus', and المشكلة 'the problem' were only attested 8 times for each. The influence of the participants' religious background in the choice of euphemisms was clearly observed. They referred to religion-based euphemisms involving religious sentiments or Qur'anic expressions, such as عُستلاء من الله 'adversity', or 'a test from God'. Two participants used the implied pronoun sit' in Arabic instead of mentioning COVID-19 openly. Other euphemistic expressions, such as امتحان 'test', عدوى 'tofter

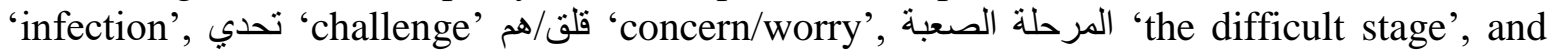
'the current circumstance' were rarely mentioned. Indeed, the participants provided a list of euphemistic responses to the first open-ended question to discuss COVID-19 indirectly. This clarifies the linguistic variation of the Jordanian Arabic speakers for coping with diseases. 


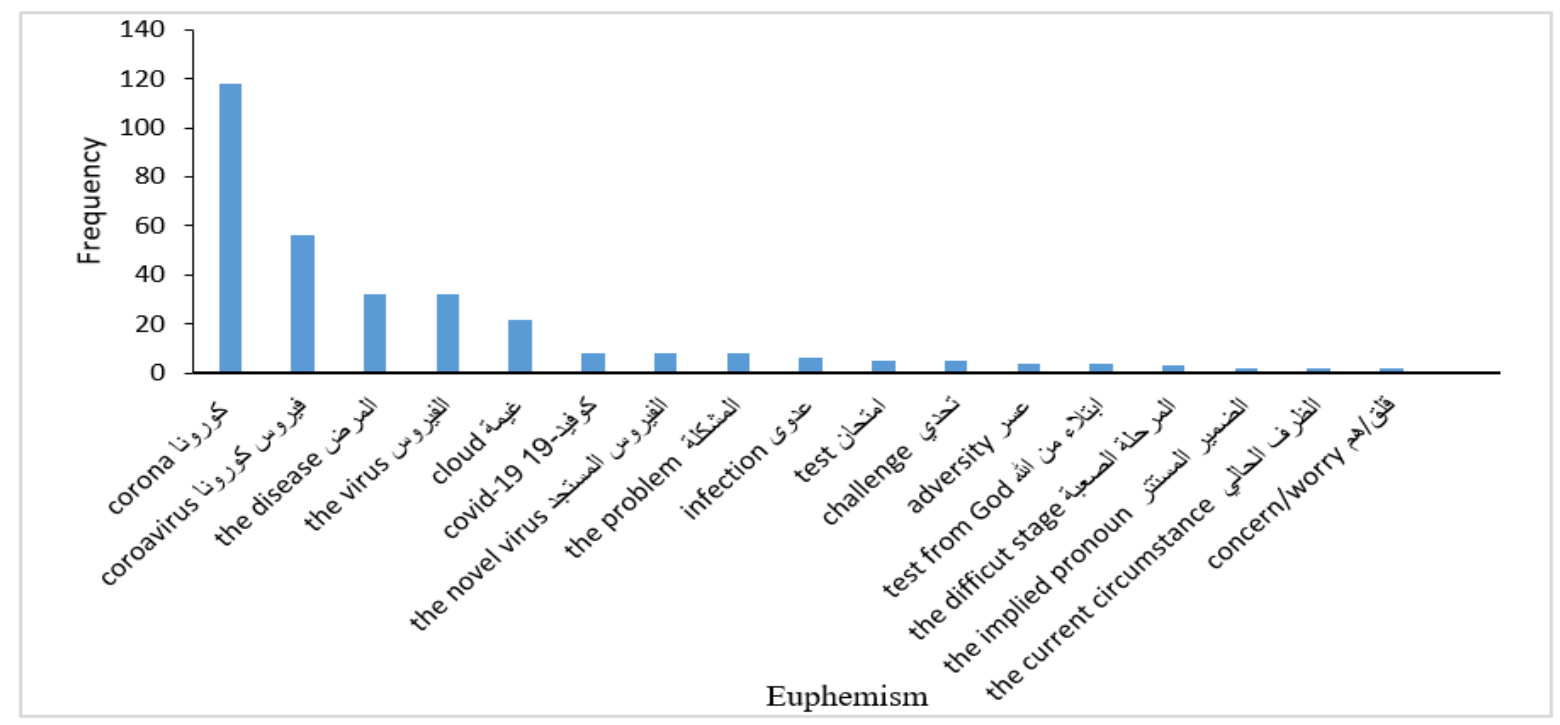

FIGURE 2. The participants' euphemistic responses for dealing with COVID-19

The second open-ended question explores dysphemistic expressions adopted by the participants for dealing with COVID-19 in daily interactions. The context in some cases requires using obscene language (Al-Qadi, 2009). Therefore, speakers resort to derogatory or direct expressions. Figure 3 shows that the word الوباء 'the pandemic' was adopted 124 times by Jordanian participants to express their apprehension of negative features of COVID-19. The 'speaking offensively' strategy (Allan and Burridge, 2006) seems to be especially noteworthy towards COVID-19 which is pervasive in the world. The word أزمة 'crisis' occupied the second rank at 68 times. This semantic usage was adopted by Jordanian participants to depict a turning point of COVID-19 outbreak globally where a dramatic increase of infections and death cases has been reported. Jordanians resorted to the dysphemism البلاء 'the affliction' 66 times since it perhaps can be easily understood literally or contextually although the ambiguity of dysphemism should be maintained in some circumstances for the purpose of achieving communicative functions. Figure 3 shows that dysphemisms محنة مصيبة calamity' and 'hardship' were mentioned 28 and 22 times respectively. These offensive expressions could be used due to their figurative language and culture-specific implications in the Jordanian community. Some participants used two dysphemistic-loaded expressions, namely, فة 'blight' and جائحة 'pandemic', relying on the current critical situation of COVID-19 pandemic worldwide. Other participants attempted to represent COVID-19 as الطاعون 'plague' based on the fact that dysphemism is mainly used to characterize a given topic in a negative way. The use of dysphemism was affected by the participants' religious beliefs when they referred to

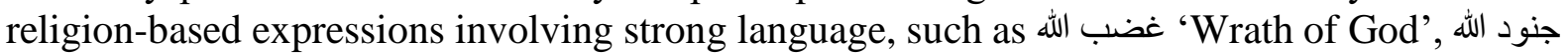
'Soldiers of God', and تحذير من الله 'a warning from God'. Other expressions with disparaging

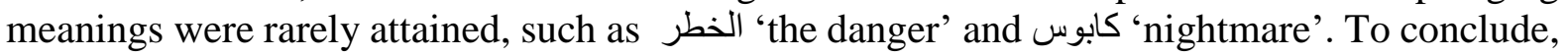
the participants introduced a number of dysphemistic terms for minimizing or reducing the negative effect of COVID-19 in societal communication. 


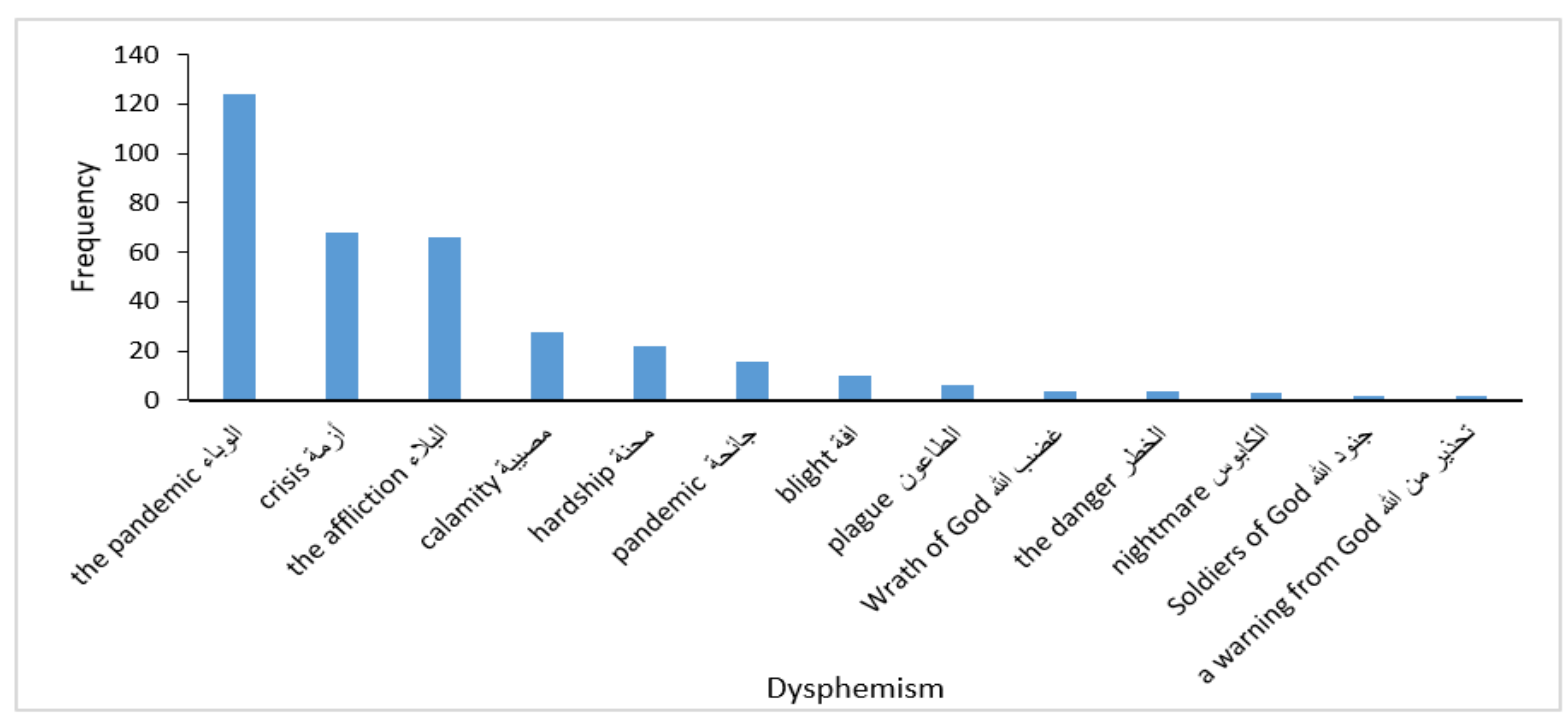

FIGURE 3. The participants' dysphemistic responses for dealing with COVID-19.

\section{CONCLUSION AND FUTURE RESEARCH}

The current study provides an understanding and linguistic analysis to what extent Jordanian Arabic speakers can use and accept euphemistic and dysphemistic terminology reflected in daily COVID-19 conversations. The results revealed that there is a linguistic variation in the production of euphemistic and dysphemistic utterances according to age, gender, and level of education. Jordanians used various euphemistic devices in COVID-19 communication to make interlocutors get along better with others, such as metaphors, shift from Arabic into English, medical terms, and scientific abbreviations. Jordanians sometimes used dysphemistic language to reduce the negative effect of COVID-19. Although the Jordanian participants generally adhered to the use of euphemistic expressions more than dysphemistic ones, both linguistic strategies were deliberately adopted in social discourse to provide a better understanding of the serious effect of COVID-19. This study concludes that the wide use of COVID-19 euphemisms and dysphemisms shows the linguistic development of the Jordanian Arabic speakers, as a result of recent educational developments, cross-culture interactions, new lifestyles, and modern social behaviours (Al-Azzam et al.; 2017)

Even though this research relies on a number of separate euphemistic and dysphemistic expressions taken directly from selected participants, conducting such researches is particularly important in the area of sociolinguistics because it provides opportunities for further investigation on the use of euphemistic and dysphemistic strategies by individuals or communities in the context of authentic conversations and in the time of global crises, such as wars and starvation. Future research may include exploring paralinguistic features of Jordanian speakers, such as hand gestures, facial expressions, eye movements, body language, and tone and pitch of voice, when discussing COVID-19 issues. Linguists are further advised to examine a larger text corpus of euphemistic and dysphemistic COVID-19 terms used by Jordanians. Since euphemism and dysphemism are culturally specific phenomena representing different attitudes towards the topic of COVID-19, the proposed questionnaire should be further employed to critically evaluate the use and strategies of COVID-19 euphemism and dysphemism in other languages, such as English. This will give a general view of the linguistic techniques used by other language speakers to persuade, control, react, or behave in COVID19 communication. It also will permit other language speakers to enhance their awareness of similar and different uses of COVID-19 euphemism and dysphemism in varied cultures. 


\section{REFERENCE}

Al-Adwan, A. (2015). Towards a Model of Euphemisation in Arabic Subtitling. Arab World English Journal. 4, 6-21.

Al-Azzam, B. Al-Ahaydib, M. Alkhowaiter, N. \& Al-Momani, H. (2017). Social and Cultural Euphemism in Saudi Arabic: A Semantic, a Pragmatic and a Sociolinguistic Analysis. Advances in Language and Literary Studies (ALLS). 8(2), 64-69.

Al-Azzeh, I. (2009). The Use of Euphemisms by Jordanian Speakers of Arabic. Unpublished M.A. thesis. Middle East University, Jordan.

Al-Khasawneh, F. (2018). An Intercultural Study of Euphemistic Strategies Used in Saudi Arabic and American English. Indonesian Journal of Applied Linguistics. 8(1), 217225.

Al-Khatib, M.A. \& Sabbah, E.H. (2008). Language Choice in Mobile Text Messages among Jordanian University Students. SKY Journal of Linguistics. 21(1), 37-65.

Allan, K. (2012). X-phemism and Creativity. Lexis. 7, 5-42.

Allan, K. \& Burridge, K. (1991). Euphemism and Dysphemism: Language Used as Shield and Weapon. New York: Oxford University Press.

Allan, K. \& Burridge, K. (2006). Forbidden Words: Taboo and the Censoring of Language. Cambridge: Cambridge University Press.

Almasaeid, A. (2016). Qur'anic Euphemisms: A Pragmatic and Translational Analysis. Saarbrücken: LAP LAMBERT Academic Publishing.

Al-Qadi, N.S. (2009). A Sociolinguistic Comparison of Euphemisms in English and Arabic. Journal of King Saud University-Language and Translation. 21(1), 13-22.

Al-Shamali, F. (1997). Facets of Euphemism in Jordan Valley Dialect. Unpublished M.A. Thesis. Yarmouk University, Jordan.

Angeli, E. (2012). Metaphors in the Rhetoric of Pandemic Flu: Electronic Media Coverage of H1N1 and Swine Flu. Journal of Technical Writing and Communication. 42(3), 203222.

Balteiro, I. (2017). Metaphor in Ebola's Popularized Scientific Discourse. Ibérica 34, 209-230.

Cameron, D. (1995). Verbal Hygiene. Routledge: London.

Concise Oxford English Dictionary. (2004). 11 ${ }^{\text {th }}$ ed. Oxford: Oxford University Press.

Crawford, M. \& Chaffin, R. (1987). Effects of Gender and Topic on Speech Style. Journal of Psycholinguistic Research, 16(1), 83-89.

Crespo Fernández, E. (2005). Euphemistic Strategies in Politeness and Face Concerns. Pragmalingüistica, 13, 77-86.

Crespo Fernández, E. (2015). Sex in Language. Euphemistic and Dysphemistic metaphors in Internet Forums. London: Bloomsbury.

Eckert, P. (1997). Age as a Sociolinguistic Variable. In: Florian Coulmas (Ed.) The Handbook of Sociolinguistics (pp. 151-167). Malden, Massachusetts: Blackwell.

ElShiekh, A.A. (2013). Euphemism, Hedging or Mystification of Responsibility? an Investigation into Contemporary Colloquial Discourse with Particular Reference to Taxi Drivers \& Undergraduate University Students in Egypt \& Jordan. International Journal of English Linguistics. 3(3), 88-99.

Farghal, M. 1993. Religious Death Terms in Arabic: A Semantico-pragmatic Perspective. International Journal of Islamic and Arabic Studies. 10(2), 15-26.

Farghal. M. (1995). Euphemism in Arabic: A Gricean Interpretation. Anthropological Linguistics. 37(3), 336-378.

Fairclough, N. (1992). Discourse and Social Change. Cambridge \& Malden: Polity Press. Fairclough, N. (1995a). Critical Discourse Analysis. London and New York: Longman.

Fairclough, N. (1995b). Media discourse. London: Edward Arnold. 
Gibbs, R.W. (1994). Poetics of Mind: Figurative Thought, Language and Understanding. New York: Cambridge University Press.

Gomez, M.C. (2009). Towards a New Approach to the Linguistic Definition of Euphemism. Language Sciences. 31(6), 725-739.

Greene, C.T. (2000). The Use of Euphemisms and Taboo Terms by Young Speakers of Russian and English. Unpublished M.A. Thesis, University of Alberta, Alberta, Canada.

Greis, N. (2000). Aspects of Modern Egyptian Arabic: Its Structure, Humor, Proverbs, Metaphors, Euphemisms and Common Expressions. Washington: Educational Resources Information Center.

Hazaymeh, O. Almutlaq, H. Jarrah, M. \& Al-Jawarneh, A. (2019). English and French Borrowed Words for Euphemism in Jordanian Arabic. International Journal of English Linguistics. 9(6), 287-291.

Holder, R.W. (2008). A Dictionary of Euphemism: How not to Say What You Mean. Oxford: Oxford University Press

Holmes, J. (1998). Women's Talk: The Question of Sociolinguistics Universals. In: J. Coasts, (Ed.). Language and Gender: A Reader (pp. 64-76). New York: Basil Blackwell.

Huang, Y. (2005). A Brief Study of the Origin, Forms and Change of English Euphemisms. US-China Foreign Language. 3, 46-48.

Jeon, H. \& Yu, H. (2016). Metaphor and Ideological Implications for MERS. Korean Studies. 72, 99-225.

Jordanian Ministry of Health COVID-19. (2020). Available online at: https://corona.moh.gov.jo/ar (Accessed August 13, 2020).

Joye, S. (2010). News Discourses on Distant Suffering: A Critical Discourse Analysis of the 2003 SARS Outbreak. Discourse \& Society. 21(5), 586-601.

Khanfar, A.M. 2012. Euphemism in Arabic: Typology and Formation. Journal of the College of Arts. University of Basrah. 61(1), 1-34.

Lakoff, R. (1975). Language and Woman's Place. Language in Society. 2(1), 45-80.

Lakoff, G. \& Johnson, M. (1980). Metaphors We Live by. Chicago: University of Chicago Press.

Lakoff, G. \& Johnson, M. (1999). Philosophy in the Flesh: The Embodied Mind and its Challenge to Western Thought. New York: Basic Books.

Leech, G. (1974). Semantics: The Study of Meaning: England: Penguin Books Ltd,

McArthur, T. (1992). The Oxford Companion to the English Language. Oxford: Oxford University Press.

Mihas, E. (2005). Non-literal Language in Political Discourse. In: LSE Working Papers in Linguistics 5: Proceedings of Workshop in General Linguistics (WIGL), 2005, UWMMadison. USA: University of Wisconsin-Milwaukee, 124-139.

Mofarrej, O.M. \& Al-Haq, F. A. (2015). A Sociolinguistic Study of Euphemistic Death Expressions in Jordanian Arabic. Arab World English Journal (AWEJ). 6(2), 110-130.

Nassar, M. \& Al-Harahsheh, A. (2020). A Socio-Pragmatic Study of the Lebanese Uprising Slogans. International Journal of English and Education. 9(3), 174-184.

Neaman, J. \& Silver, C. (1983a). Kind Words: a Thesaurus of Euphemisms. New York: Facts on File.

Neaman, J. \& Silver, C. (1983b). Dictionary of Euphemism. London: H. Hamilton.

A, Aolymat, I, Shahbaz, H. \& Holley, R. (2020a). Knowledge and Information Sources About COVID-19 Among University Students in Jordan: A Cross-Sectional Study. Frontiers in Public Health. 8(254), 1-9.

Olaimat. A, Aolymat, I, Nour, E. Shahbaz, H. \& Holley, R. (2020b). Attitudes, Anxiety, and Behavioral Practices Regarding COVID-19 among University Students in Jordan: A 
Cross-Sectional Study. The American journal of tropical medicine and hygiene. 00(0), $1-7$.

Olimat $_{2}$ S. N. (2018). Developing a Model for Translating Euphemism in the Qur'an: an Intratextual- and Contextual-based Approach. Advances in Language and Literary Studies. 9(6), 101-111.

Olimat S. N. (2019a). Euphemism in the Qur'an: Corpus-based Linguistic Analysis and Intratextual- and Contextual-based Translation. Unpublished Ph.D. Thesis, University of Leeds, Leeds, UK.

S. N. (2019b). Euphemism in the Qur'an: A Corpus-based Linguistic Approach. International Journal of Computational Linguistics (IJCL). 10(2), 16-32.

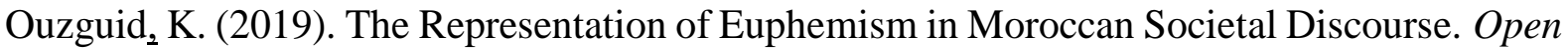
Journal of Social Sciences. 7, 243-251.

Rababah, H. A. (2014). The Translatability and Use of X-Phemism Expressions (XPhemization): Euphemisms, Dysphemisms and Orthophemisms in the Medical Discourse. Studies in Literature and Language. 9(3), 229-240.

Rabab'ah, G. \& Al-Qarni, A.M. (2012). Euphemism in Saudi Arabic and British English. Journal of Pragmatics. 44(6-7), 730-743.

Rawson, H. (1981) A Dictionary of Euphemisms and other Doubletalk. New York: Crown Publishers, Inc.

Ren, C. \& Yu, H. (2013). Euphemism from Sociolinguistics Perspective. Studies in Sociology of Science, 4(4), 45-48.

Shin, J. (2016). Metaphorical Analogies for 'MERS' in Korean Newspaper Headlines Discourse and Cognition. 23(2), 51-19

Stern $_{2}$ G. (1931). Meaning and Change of Meaning. Bloomington: Indiana University Press.

Tayler, M. \& Ogden, J. (2005). Doctors' Use of Euphemisms and Their Impact on Patients' Beliefs about Health: An Experimental Study of Heart Failure. Patient Education and Counseling. 57, 321-326.

Trčková, D. (2015). Representations of Ebola and its Victims in Liberal American Newspapers. Topics in Linguistics. 16, 29-41.

Van Dijk, T.A. (1993). Principles of Critical Discourse Analysis. Discourse and Society. 4(2), 249-283.

Wallis, P. \& Nerlich, B. (2005). Disease Metaphors in New Epidemics: the UK Media Framing of the 2003 SARS Epidemic. Social Science \& Medicine. 60, 2629-2639.

Wardhaugh, R. (2006). An Introduction to Sociolinguistics. Malden: Blackwell Publishing.

Warren, B. 1992 What Euphemisms Tell Us about the Interpretation of Words. Studia Linguistica, 46(2), 128-172.

Weiss, G. \& Wodak, R. (2003). Critical Discourse Analysis: Theory and Interdisciplinarity. Basingstoke: Palgrave Macmillan.

Williams, J. (1975). Origins of the English Language. New York: The Free Press.

Wodak, R. \& Meyer, M. (2009). Methods of Critical Discourse Analysis. $2^{\text {nd }}$ ed. London: Sage. 


\section{APPENDIX A}

(A translated form of the questionnaire)

Dear respondent,

You are being invited to take part in a scientific research titled "COVID-19 Pandemic in Jordanian Arabic: Euphemistic and Dysphemistic Strategies". Before you decide, it is important for you to understand why the research is being done and what it will involve. Please read the following information carefully and discuss it with others if you wish. Ask us if there is anything that is not clear or if you would like more information. Take time to decide whether you wish to take part or not.

This research aims to examine the linguistic development and behaviours of the Jordanian society for dealing with COVID-19 global outbreak. It also attempts to identify the most common linguistic devices used by Jordanian speakers for discussing the topic of COVID-19. Please be aware that all the information that we collect about you and during the course of the research will remain strictly confidential, and only anonymised data will be published. You will not be able to be identified in any reports or publications. Your participation is entirely voluntary, and you can withdraw at any time. You do not have to answer any questions you do not want, and you do not have to give a reason. We believe there are no known risks associated with this research.

- Do you wish to participate in the research? Yes

\section{Demographic Information:}

Age

- $16-19.99$

- 20-39.9

- $40-59.9$

- 60 or above

\section{Gender}

- Female

- Male

\section{Educational Level}

- Secondary school or less

- Bachelor Degree

- Graduate Studies 


\section{First Section: Closed-ended Questions}

Q 1: Do you prefer to use euphemisms when communicating about COVID-19?
Yes
No

Q 2: Do you prefer to use dysphemisms when communicating about COVID-19?

Yes $\quad$ No

Q 3: Do you prefer to shift from Arabic into English when communicating about COVID-19?

Yes $\quad$ No

Q 4: Do you prefer to use the medical abbreviated term 'COVID-19' when communicating about COVID-19?

Yes $\quad$ No

\section{Second Section: Open-ended Questions}

Q 1: What are the most common euphemistic expressions for COVID-19 that you are using in linguistic communication (provide as many responses as possible)?

Q 2: What are the most common dysphemistic expressions for COVID-19 that you are using in linguistic communication (provide as many responses as possible)?

Many thanks for your time and cooperation!

The researcher

\section{ABOUT THE AUTHOR}

Sameer Olimat is an assistant professor of English at Al-Balqa Applied University, Jordan. He has recently graduated from the University of Leeds, UK. He is interested in the areas of translation studies, computational linguistics, and sociolinguistic. He is the founder of Leeds Corpus of Euphemisms in the Qur'an http://corpus.leeds.ac.uk/euphemismolimat/. He participated in national and international peer-reviewed conferences. He published different articles in peer-reviewed and specialized journals. 